\title{
The Effect of Yellow and Red-fleshed Watermelon Rind Powder Dietary Supplementation on Plasma Metabolites in Indigenous Chickens
}

\author{
Edi Erwan ${ }^{1 *}$, Evi Irawati ${ }^{1}$, Alwis Nazir ${ }^{2}$, Deni Fitra ${ }^{1}$, Muhammad Rodiallah ${ }^{1}$, and Vishwajit Sur Chowdhury ${ }^{3}$ \\ ${ }^{I}$ Department of Animal Science, Faculty of Agriculture and Animal Science, State Islamic University of Sultan Syarif Kasim Riau, Pekanbaru, Riau, Indonesia \\ ${ }^{2}$ Informatics Engineering Department, Faculty of Science and Technology, State Islamic University of Sultan Syarif Kasim Riau, Pekanbaru, Riau, Indonesia \\ ${ }^{3}$ Faculty of Arts and Science, Kyushu University, Fukuoka 819-0395, Japan \\ *Corresponding author's Email: erwan_edi@yahoo.com; ORCID: 0000-0002-5306-1582
}

Received: 19 October 2021

Accepted: 14 December 2021

\begin{abstract}
Watermelon rind (WR) content is rich in citrulline (Cit). Oral administration of L-Cit could improve thermotolerance in layer and broiler chickens due to its hypothermic role. Additionally, chronic supplementation of WR dried powder (WRP) increases feed intake but makes no changes to the body temperature. The objective of the current study was to evaluate the effect of yellow and red WRP supplementation on plasma metabolites as well as and liver and spleen weight. In Experiment 1, a total of 20 indigenous chicks aged 1-14 days were treated with different doses of yellow WRP $(0 \%, 2 \%, 4 \%$, and $6 \%)$ supplemented in a commercial diet. Similarly, 20 indigenous chicks with the age range of 1-14 days were treated in Experiment 2 with different doses of red WRP (0\%, 2\%, 4\%, and 6\%) supplemented in a commercial diet. The obtained results indicated that the yellow WRP supplementation caused a linearly increased plasma total cholesterol (TCHO). However, the red WRP neither increased plasma TCHO linearly nor plasma glucose (Glu), although plasma Glu concentration significantly increased by $6 \%$ red WRP supplementation. These results suggest that supplementation of both yellow and red WRP to a commercial diet could change the concentrations of plasma metabolites, while the effect of yellow WRP may be different, compared to that of red WRP.
\end{abstract}

Keywords: Glucose, Indigenous chicks, Plasma metabolites, Total cholesterol, Watermelon rind powder

\section{INTRODUCTION}

Nowadays, both global warming and summer heat stress (HS) are becoming serious concerns all over the world. As reported by the Intergovernmental Panel on Climate Change (IPCC), the global surface temperature has been increasing (IPCC, 2021). Hence, summer HS is becoming more unbearable in tropical and subtropical countries. Since the environmental temperature is steadily increasing over the globe, HS is considered one of the major challenges for poultry production in many countries. Summer HS causes a great economic loss in the commercial poultry sector. Leeson (1986) reported that high ambient temperature (HT) is the most inhibiting factor for poultry production in the hot regions because birds cannot quickly dissipate the excess heat produced under HT, which subsequently leads to decreased performance as a result of lower body weight gain in broiler chickens and low egg production in layer chickens with increasing rate of mortality (Teeter et al., 1985; Quinteiro-Filho et al., 2010). Compared to other domestic animals, poultry is more sensitive to HT (Geraert et al., 1993) since they lack sweat glands and rely on evaporative cooling (panting) to keep them cool (Ensminger et al., 1990). There are some physiological changing aspects, such as glucose, hormones, leukocytes, electrolytes, and functions of the organ in responding to HT (Geraert et al., 1996). It was further reported that HT negatively affects growth performances and some physiological properties (Tao et al., 2006; Chowdhury et al., 2012; Chowdhury et al., 2014) and immunological adaptations of laying hens 
(Star et al., 2009). Therefore, it is important to examine biochemical parameters in the blood, such as plasma metabolites, plasma catecholamines to understand the adaptation level of animals to HT (Erwan et al., 2014). Numerous reports have shown that in an HT, the concentration of plasma glucose (Glu) and total cholesterol (TCHO) decrease in the blood, which is an indicator of disruption in homeostasis (Ocak and Guney, 2010; Ribeiro et al., 2016; Ribeiro et al., 2018). Some nutritional supplementations have been suggested to eliminate the detrimental effects of HT on the body temperature of poultry. For instance, providing essential or non-essential amino acids with or without conjugated with emulsifier of lauric acid in their diets could reduce the effects of HT in poultry (Erwan et al., 2013; Erwan et al., 2014; Yoshida et al., 2015). However, nutritional manipulation with low-cost involvement is a common approach in the poultry industry (Shane, 1988).

It was revealed that the body temperature of layer chicks decreased when L-citrulline (L-Cit) was orally administrated (Chowdhury et al., 2015). It was further reported that the oral administration of L-Cit can be beneficial to mitigate HS response in broilers (Chowdhury et al., 2021). However, using synthetic commercial L-Cit in chickens' ration has not yet been recommended since essential amino acid, arginine, can synthesis Cit as a byproduct of nitric oxide production (Fleming and Busse, 2003). Hence, one alternative strategy might be using a natural source of L-Cit from watermelon (Citrullus lanatus). This fruit is a widely cultivated crop around the world and is also considered as the largest cultivated member of the Cucurbitaceae family (Ibrahim et al., 2013). King et al. (2009) reported that the flesh color of watermelon can be found in eight colors, namely, white, salmon yellow, orange, crimson red, scarlet red, pale yellow, canary yellow, and green. Instead of its flesh, watermelon rind (WR) as an agricultural waste has been reported to be a rich source of L-Cit (Rimando and Perkins-Veazie, 2005). The different colors of the watermelon flesh affect carotenoid contents (Zhao et al., 2013). It was reported that WR extract (WRE) contains $6638 \mathrm{pmol} / \mathrm{mg}$ of L-Cit (Nguyen et al., 2019).

With this in mind, the current study aimed to examine the effects of supplementation of WR from different colors of fruit fresh, especially yellow or red WR powder (WRP) as a natural source of L-Cit on plasma metabolites in indigenous chicks, especially in Indonesia as there is no report on this issue. The second purpose of the current study was to investigate whether the supplementation of yellow or red WRP can affect the weights of the spleen and liver in indigenous chicks.

\section{MATERIALS AND METHODS}

\section{Ethical approval}

This research was conducted under strict regulations in accordance with the recommendations in the Guide for the Care and Use of Animal, at the Faculty of Agriculture and Animal Science, State Islamic University of Sultan Syarif Kasim Riau, Pekanbaru, Indonesia.

\section{Supplementation of yellow WRP on plasma metabolites as well as weights of spleen and liver (Experiment 1)}

One day-old indigenous chicks were raised at the Poultry Division Field Laboratory, Faculty of Agriculture and Animal Science, State Islamic University of Sultan Syarif Kasim Riau, Indonesia. The chicks were housed in a wire-meshed cage $(50 \times 35 \times 33 \mathrm{~cm})$ in a group of $20-25$ and with continuous light for 2 weeks. The commercial ration and water were provided ad libitum. The formulation of ration is presented in Table 1 .

Table 1. The nutrient content of the commercial ration provided for indigenous chicks

\begin{tabular}{lc}
\hline Nutrient & Commercial ration \\
\hline Crude Protein (\%) & 23.50 \\
Crude Fiber (\%) & 1.88 \\
Crude Fat (\%) & 5.87 \\
$\mathrm{Ca}(\%)$ & 0.29 \\
$\mathrm{P}(\%)$ & 0.15 \\
$\mathrm{ME}(\mathrm{Kcal} / \mathrm{kg})$ & 3,050 \\
\hline
\end{tabular}

Ca: Calcium, P: Phosphor, ME: Metabolizable Energy; *Commercial feed: CP511 PT, Charoen Pokphand, Indonesia; **Mineral Premix: Vitamin A (12000 IU), D3 (2000 IU), E (20 mg), K3 (3 mg), B2 (7 mg), B3 $(12 \mathrm{mg})$, B5 $(3 \mathrm{mg})$, B12 $(0.03 \mathrm{mg})$, biotin $(0.1 \mathrm{mg})$, choline chloride (300 mg), Mn (130 mg), Fe (70 mg), Zn (60 mg), Cu (12 mg), I (1 mg), $\mathrm{Se}(0.2 \mathrm{mg})$, and adequate antioxidant.

The treatments included the supplementation of different levels of yellow WRP $(0,2,4$, and 6\%) in commercial diets of indigenous chicks from day 1 to 14 days of age. At the end of the experiments, chicks were decapitated following anesthesia with chloroform. Blood samples were collected under chloroform anesthesia in heparinized tubes and centrifuged for 15 minutes at 5000 $\mathrm{g}$, then plasma was collected and stored at $20^{\circ} \mathrm{C}$ until the analysis. 
Supplementation of red WRP on plasma metabolites as well as weights of spleen and liver (Experiment 2)

Similar to Experiment 1, Indigenous chicks in this experiment were raised in a cage $(50 \times 35 \times 31 \mathrm{~cm})$ for 2 weeks. The treatments included supplementation of different levels of red WRP $(0,2,4$, and 6\%) in commercial diets of old indigenous chicks aged 1-14 days. At the end of the experiments, chicks were quickly decapitated following anesthesia with chloroform. The blood samples were collected in heparinized tubes and centrifuged for 15 minutes at $5000 \mathrm{~g}$, and the plasma was collected and stored at $20^{\circ} \mathrm{C}$ until the analysis. After that, the weights of the spleen and liver were recorded.

\section{Plasma metabolites measurement}

The plasma metabolites, including Glu, TCHO, total protein (TP), triacylglycerol (TG) were measured by Microlab 300 (Vital Scientific, Netherland). The samples were assayed together and in a random sequence for each metabolite.

\section{Statistical analysis}

In Experiments 1 and 2, regression equations were used for data on the doses of WRP and concentrations of plasma metabolites. In both Experiments 1 and 2, data were analyzed by one-way ANOVA and regression equations while the Tukey-Kramer test was performed as a post-doc test. Significant differences were denoted as $p<$ 0.05 . Values were presented as means \pm S.E.M. Statistical analysis was performed using commercially available package SAS (1998). Thompson rejection test was used for all data before the analysis to eliminate outliers ( $\mathrm{p}<$ 0.05 ), and the rest of the data were used for analysis.

\section{RESULTS}

Effects of yellow WRP dietary supplementation in commercial diets on plasma metabolites as well as weights of the liver and spleen of indigenous chicks (Experiment 1)

Table 2 shows the effects of supplementation of different levels of yellow WRP on plasma metabolites. The findings indicated a significant $(\mathrm{p}<0.05)$ positive correlation between the levels of yellow WRP and TCHO concentration $\left(109[\mathrm{SE}=10]+5.62[\mathrm{SE}=2] \mathrm{X}, \mathrm{R}^{2}=\right.$ 0.368). However, plasma Glu, TP, and TG were not changed by the dietary supplementation of yellow WRP (Table 2). As shown in Figure 1, different treatments including yellow WRP led to no significant effect on weights of the liver and spleen ( $p>0.05)$.

Table 2. Effects of supplementation of several doses of yellow watermelon rind dried powder on plasma metabolites in indigenous chicks

\begin{tabular}{|c|c|c|c|c|}
\hline $\begin{array}{ll}\text { Parameter } & \text { Yellow watermelon dried rind powder }(\%) \\
\end{array}$ & $\mathbf{0}$ & 2 & 4 & 6 \\
\hline Glucose $(\mathrm{mg} / 100 \mathrm{ml})$ & $263 \pm 10$ & $273 \pm 23$ & $371 \pm 63$ & $246 \pm 21$ \\
\hline Total cholesterol $(\mathrm{mg} / 100 \mathrm{ml})$ & $114 \pm 18$ & $108 \pm 15$ & $139 \pm 6$ & $143 \pm 8$ \\
\hline Triacylglycerol $(\mathrm{mg} / 100 \mathrm{ml})$ & $98 \pm 37$ & $179 \pm 66$ & $246 \pm 2$ & $74 \pm 9$ \\
\hline
\end{tabular}

Values are means \pm SEM. Total cholesterol $=109[\mathrm{SE}=10]+.5 .62[\mathrm{SE}=2] \mathrm{X}, \mathrm{R}^{2}=0.368$
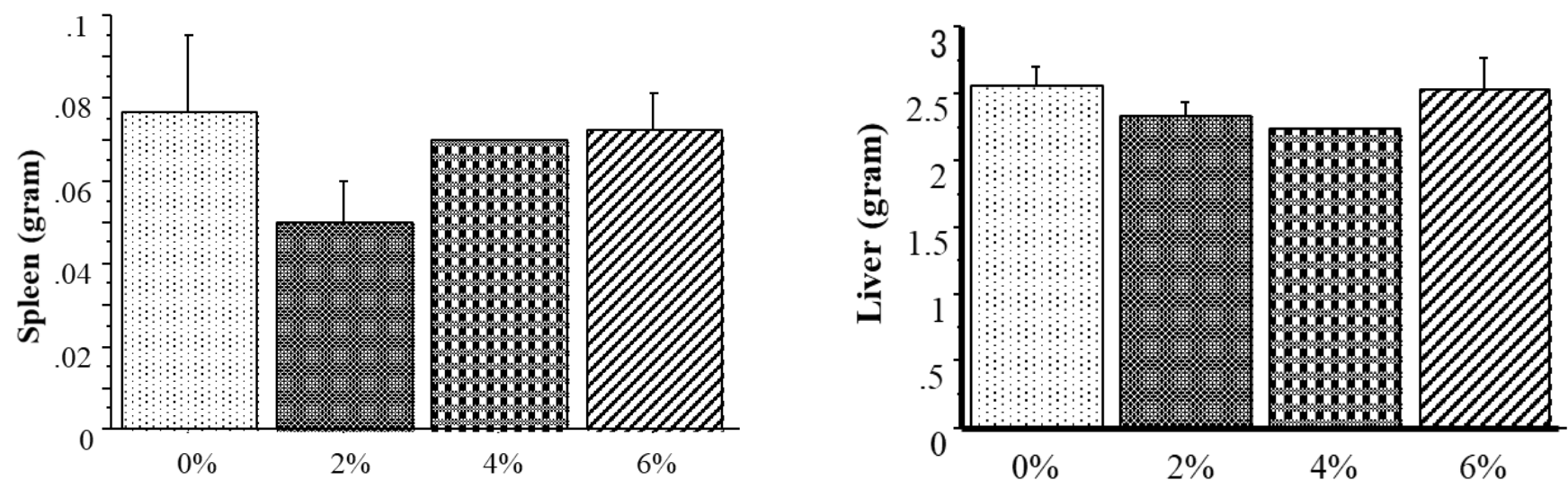

Figure 1. Effects of supplementation of yellow watermelon rind dried powder on the weights of liver and spleen in indigenous chicks 
Effects of different levels of red WRP dietary supplementation in commercial diet on plasma metabolites as well as weights of the liver and spleen of indigenous chicks (Experiment 2)

Table 3 shows the effects of dietray supplementation of different levels of red WRP in commercial diet on plasma metabolites. Treatments in this experiment could significantly affect plasma Glu concentration $(p<0.05)$ and there was a significant positive correlation $(\mathrm{p}<0.05)$ between the dose of red WRP and Glu concentration (253 $\left.[\mathrm{SE}=8]+4[\mathrm{SE}=2] \mathrm{X}, \mathrm{R}^{2}=0.29\right)$. In addition, a positive significant correlation was observed between the dose of red WRP and TCHO concentration (112 [SE=12] + 6 [SE $=3] \mathrm{X}, \mathrm{R}^{2}=0.27, \mathrm{p}<0.05$ ).

As shown in Figure 2, different levels of red WRP dietary supplementation in commercial diet had no significant effect on the weights of spleen and liver in indigenous chicks

Table 3. Effects of supplementation of several doses of red watermelon rind dried powder on plasma metabolites in indigenous chicks

\begin{tabular}{|c|c|c|c|c|}
\hline $\begin{array}{ll}\text { Parameter } & \text { Red watermelon dried rind powder }(\%) \\
\end{array}$ & $\mathbf{0}$ & 2 & 4 & 6 \\
\hline Glucose $(\mathrm{mg} / 100 \mathrm{ml})$ & $247 \pm 0^{\mathrm{a}}$ & $272 \pm 10^{\mathrm{ab}}$ & $259 \pm 3^{\mathrm{a}}$ & $281 \pm 4^{b}$ \\
\hline Total protein $(\mathrm{g} / 100 \mathrm{ml})$ & $3.40 \pm 0.1$ & $2.63 \pm 0.1$ & $2.30 \pm 0.1$ & $2.65 \pm 0.1$ \\
\hline Triacylglycerol (mg/100 ml) & $226 \pm 0$ & $171 \pm 35$ & $109 \pm 36$ & $174 \pm 22$ \\
\hline
\end{tabular}

$\overline{a, b}$ Means different superscripts in the same row were significantly different at $\mathrm{p}<0.05$


Figure 2. Effects of dietary supplementation of red Watermelon rind dried powder on the weights of spleen and liver in indigenous chicks

\section{DISCUSSION}

In Experiment 1, it was clearly observed that when yellow WRP was supplemented to the diet of indigenous chicks, no significant changes were observed in their plasma metabolites. However, the yellow WRP level increased the concentration of plasma TCHO linearly. As far as the researchers are concerned, the current study has been the first attempt to recognize that yellow WRP could be considered as a potential factor in increasing plasma TCHO. These findings are inconsistent with a previous report (Poduri et al., 2013) indicating that dietary supplementation of WRE decreased plasma TCHO in mice. The discrepancies in the TCHO concentration in response to yellow WRP were due to the fact that Poduri et al. (2013) used the fresh extract of skin, pulp, and seeds of the watermelon. However, the current study relied on the dried substance of the skin and pulp. Moreover, species differences could be another factor leading due to such difference as the current study was performed on indigenous chicks while Poduri et al. (2013) used mice. The WRP obtained from the yellow watermelon in the current study had no significant correlation with plasma Glu, TP, and TG implying that 14 days of supplementation 
of yellow WRP may not affect the metabolism of these three components in indigenous chicks.

Regarding Experiment 2, supplementation of red WRP doses increased Glu. This result is not in line with Chowdhury et al. (2017) who revealed that plasma Glu concentration decreased when layer chicks were given oral synthetic L-Cit for 90 minutes. Furthermore, Poduri et al. (2013) demonstrated that dietary supplementation of WRE decreased plasma TCHO in mice, meanwhile Parmar and Kar (2008) revealed that and LDL-cholesterol concentrations were increased by dietary supplementation of WR in Wistar rats. These discrepancies in the Glu or TCHO concentrations in response to WRP may be due to some factors, such as different types of watermelon as well as experimental duration, doses, or strains. Recently, it has been demonstrated that the content of L-Cit was higher in red WRP than that of yellow WRP (unpublished data). Therefore, there is a need to conduct further investigation to determine the factors involved in this disparity.

\section{CONCLUSION}

It seems that this is the first study to report that both yellow and red WRP supplementation to commercial diets could modulate plasma TCHO or Glu in indigenous chicks. Red WRP has potentially higher modulation of the energy metabolism than yellow WRP since it modulated plasma Glu in indigenous chicks. It could be suggested that implementation of using red WRP in the diet for supporting energy metabolism in indigenous chickens.

\section{DECLARATIONS}

\section{Competing interests}

The authors declare no conflicts of interests.

\section{Acknowledgments}

All authors are very grateful to the Rector of State Islamic University of Sultan Syarif Kasim Riau, Indonesia for supporting. This work was supported by The Directorate of Islamic Religious Higher Education of The Indonesian Ministry of Religion through a Grant-in-Aid for Scientific Research no 4842 to EE.

\section{Authors' contributions}

Edi Erwan conducted the research, prepared data, performed the statistical analysis and wrote draft article. Evi Irawati, Alwis Nazir, Deni Fitra, and Muhammad Rodiallah and Vishwajit Sur Chowdhury revised the article. All authors checked and approved the final version of the manuscript.

\section{Ethical considerations}

Ethical issues including plagiarism, consent to publish, misconduct, data fabrication and/or falsification, double publication and/or submission, and redundancy have been checked by the authors.

\section{REFERENCES}

Chowdhury VS, Tomonaga S, Nishimura S, Tabata S, and Furuse M (2012). Physiological and behavioral responses of young chicks to high ambient temperature. The Journal of Poultry Science, 49: 212-218. DOI: https://www.doi.org/10.2141/jpsa.011071

Chowdhury VS, Tomonaga S, Ikegami T, Erwan E, Ito K, Cockrem JF, and Furuse M (2014). Oxidative damage and brain concentrations of free amino acid in chicks exposed to high ambient temperature. Comparative Biochemistry and Physiology: Part A, 169: 70-76. DOI: http://www.dx.doi.org/10.1016/j.cbpa.2013.12.020

Chowdhury VS, Shigemura A, Erwan E, Ito K, Bahry MA, Tran V, and Furuse M (2015). Oral administration of Lcitrulline, but not L-arginine or L-ornithine, acts as a hypothermic agent in chicks. The Journal of Poultry Science, 52: 331-335. DOI: https://www.doi.org/10.2141/jpsa.0150014

Chowdhury VS, Han G, Bahry MA, Tran PV, Do PH, Yang H, and Furuse M (2017). L-Citrulline acts as potential hypothermic agent to afford thermotolerance in chicks. Journal Thermal Biology, 69: 163-170. DOI: https://www.doi.org/10.1016/j.jtherbio.2017.07.007

Chowdhury VS, Ouchi Y, Han G, Eltahan HM, Haraguchi S, Miyazaki T, Shiraishi JI, Sugino T, and Bungo T (2021). Oral administration of L-citrulline changes the concentrations of plasma hormones and biochemical profile in heat-exposed broilers. Animal Science Journal, 92(1): e13578. Available at: https://pubmed.ncbi.nlm.nih.gov/34235825/

Ensminger ME, Oldfield JE, and Heinemann WW (1990). Feeds and nutrition. The Ensminger Publishing Company, Clovis. CA, Pearson pp. 8-120. Available at: https://www.pearson.ch/HigherEducation/Pearson/EAN/97 80941218085/Feeds-and-Nutrition

Erwan E, Chowdhury VS, Ito K, and Furuse M (2013). LauroylL-aspartate decreased food intake and body temperature in neonatal chicks. Pharmacology Biochemistry and Behavior, 13: 7-11. DOI: https://www.doi.org/10.1016/j.pbb.2013.10.010

Erwan E, Chowdhury VS, Nagasawa M, Goda R, Otsuka T, Yasuo S, and Furuse M (2014). Oral administration of Daspartate, but not Laspartate, depresses rectal temperature and alters plasma metabolites in chicks. Life Sciences, 109: 65-71. DOI: https://www.doi.org/10.1016/j.lfs.2014.05.015

Fleming I, and Busse R (2003). Molecular mechanisms involved in the regulation of the endothelial nitric oxide synthase. 
American Journal Physiology Regulatory Integrative and Comparative Physiology, 284(1): 1-12. DOI: https://www.doi.org/10.1152/ajpregu.00323.2002

Geraert PA, Guillaumin S, and Leclercq B (1993). Are genetically lean broilers more resistant to hot climate? British Poultry Science, 34: 643-653. DOI: https://www.doi.org/10.1080/00071669308417623

Geraert PA, Padilha JC, and Guillaumin S (1996). Metabolic and endocrine changes induced by chronic heat exposure in broiler chickens: Growth performance, body composition and energy retention. British Journal of Nutrition, 2: 195204. DOI: https://www.doi.org/10.1017/BJN19960124

Intergovernmental Panel on Climate Change (IPCC) (2021). The physical science basis. Contribution of working group I to the sixth assessment report of the intergovernmental panel on climate change. Available at: https://www.ipcc.ch/report/ar6/wg1/downloads/report/IPC C_AR6_WGI_Full_Report_smaller.pdf

King SR, Davis AR, and Bang H (2009). New flesh colors in watermelon? HortScience, 44: 576. Available at: https://www.ars.usda.gov/research/publications/publication ??seqNo115=237332

Leeson S (1986). Nutritional considerations of poultry during heat stress. World's Poultry Science Journal, 42: 69-81. DOI: https://www.doi.org/10.1079/WPS19860007

Nguyen LTN, Han G, Yang H, Ikeda H, Eltahan HM, Chowdhury VS, and Furuse M (2019). Dried watermelon rind mash diet increases plasma L-citrulline level in chicks. The Journal of Poultry Science, 56: 65-70. DOI: https://www.doi.org/10.2141/jpsa.0180018

Ocak S, and Guney O (2010). Physiological responses and some blood parameters of bucks under Mediterranean climate condition. Anadolu Journal of Agricultural Sciences, 25: 113-119. Available at: https://dergipark.org.tr/tr/download/article-file/187753

Parmar HS, and Kar A (2008). Possible amelioration of atherogenic diet induced dyslipidemia, hypothyroidism and hyperglycemia by the peel extracts of Mangifera indica, Cucumis melo and Citrullus vulgaris fruits in rats. Biofactors, 33: 13-24. DOI: https://www.doi.org/10.1002/biof.5520330102

Poduri A, Rateri DL, Saha SK, Saha S, and Daugherty A (2013). Citrullus lanatus 'sentinel' (watermelon) extract reduces atherosclerosis in LDL receptor-deficient mice. The Journal of Nutritional Biochemistry, 24(5): 882-886. DOI: https://www.doi.org/10.1016/j.jnutbio.2012.05.011

Ibrahim M, Reidah A, Arráez-Román D, Segura-Carretero A, and Fernández-Gutiérrez A (2013). Profiling of phenolic and other polar constituents from hydro-methanolic extract of watermelon (Citrullus lanatus) by means of accuratemass spectrometry (HPLC-ESI-QTOF-MS), Food Research International, 51(1): 354-362. DOI: https://www.doi.org/10.1016/j.foodres.2012.12.033

Ribeiro NL, Costa RG, Pimenta Filho EC, Ribeiro MN, and
Bozzi R (2018). Effects of the dry and the rainy season on endocrine and physiologic profiles of goats in the Brazilian semi-arid region. Italian Journal Animal Science, 17: 454461.

https://www.doi.org/10.1080/1828051X.2017.1393320

Ribeiro NL, Costa RG, Pimenta Filho EC, Ribeiro MN, Crovetti A, Saraiva EP, and Bozzi R (2016). Adaptive profile of Garfagnina goat breed assessed through physiological, haematological, biochemical and hormonal parameters. Small Ruminant Research, 144: 236-241. DOI: https://www.doi.org/10.1016/j.smallrumres.2016.10.001

Statistical Analysis System (SAS) (1998). Statview, version 5. SAS Institute, Cary. Available at: https://www.sas.com/en_us/software/stat.html

Rimando AM, and Perkins-Veazie PM (2005). Determination of citrulline in watermelon rind. Journal of Chromatography A, 1078: 196-200. DOI: https://www.doi.org/10.1016/j.chroma.2005.05.009

Shane SM (1988). Factors influencing health and performance of poultry in hot climates. Critical Reviews in Poultry Biology, 1 : $247 . \quad$ DOI: https://www.doi.org/10.3382/ps.2008-00560

Star L, Juul-Madsen HR, Decuypere E, Nieuwland MGB, De Vries Reilingh G, van den Brand H, Kemp B, and Parmentier HK (2009). Effect of early life thermal conditioning and immune challenge on thermotolerance and humoral immune competence in adult laying hens. Poultry Science, 88: 2253-2261. DOI: https://www.doi.org/10.3382/ps.2008-00373

Tao X, Zhang ZY, Dong H, Zhang H, and Xin H (2006). Responses of thyroid hormones of market-size broilers to thermoneutral constant and warm cyclic temperatures. Poultry Science, 85: 1520-1528. DOI: https://www.doi.org/10.1093/ps/85.9.1520

Teeter RG, Smith MO, Owens FN, Arp SC, Sangiah S, and Breazile JE (1985). Chronic heat stress and respiratory alkalosis: Occurrence and treatment in broiler chicks. Poultry Science, 64: 1060-1064. DOI: https://www.doi.org/10.3382/ps.0641060

Quinteiro-Filho WM, Ribeiro A, Ferraz-de-Paula V, Pinheiro ML, Sakai M, Sá LR, Ferreira AJ, and Palermo-Neto J (2010). Heat stress impairs performance parameters, induces intestinal injury, and decreases macrophage activity in broiler chickens. Poultry Science, 89: 19051914. DOI: https://www.doi.org/10.3382/ps.2010-00812

Yoshida J, Erwan E, Chowdhury VS, Ogino Y, Shigemura A, Denbow D, and Furuse M (2015). comparison of centrally injected tryptophan-related substances inducing sedation in acute isolation stress-induced neonatal chicks. Pharmacology Biochemistry and Behavior, 129: 1-6. DOI: http://www.doi.org/10.1016/j.pbb.2014.11.016

Zhao W, Pin LV, and Gu H (2013). Studies on carotenoids in watermelon flesh. Agricultural Sciences, 4: 13-20. DOI: http://www.dx.doi.org/10.4236/as.2013.47A003 